\title{
Dynamics of land use in a rural settlement in the Brazilian Legal Amazon
}

A dinâmica do uso da terra em um assentamento rural na Amazônia Legal brasileira

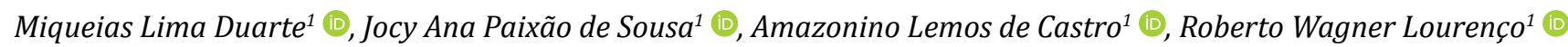

\begin{abstract}
A B S T RACT
Deforestation in the Amazon has reached alarming numbers in recent decades. The main factors causing this issue are not only large and medium-sized farmers, land grabbing, and illegal mining but also agrarian reform settlements, which may be contributing to the increase in deforestation rates. In this context, this study aims to evaluate the dynamics of land use in the rural settlement Santo Antônio do Matupi, located in the south of the State of Amazonas. This time-series study analyzed changes in land use and land cover from 1992 to 2018 using supervised classification techniques. In this scenario, simulations were carried out of the dynamics of land use for the period between 2028 and 2038 using the cellular automaton method of Markov (CAMARKOV). The results show that, in the studied period, the greatest losses were in primary forests and that the most critical period of deforestation rates recorded was from 2004 to 2018 when $63.28 \%$ of the area was converted into pastures. Future scenarios based on the period studied indicate losses of up to $5.26 \%$ of areas occupied by forests by 2028 , and a further $5.60 \%$ by 2038 , exceeding $80 \%$ of the total area deforested in the settlement. This study demonstrates that the current model of land use and occupation practiced in the settlement is unsustainable and that future scenarios are worrying. This situation highlights a need to effectively implement programs that aim a sustainable rural development in the settlement, in addition to monitoring and controlling deforestation, designed for current managers and other sectors of the society concerned with the conservation and preservation of forests.
\end{abstract}

Keywords: Amazon biome; agrarian reform; deforestation; CAMarkov model.

\begin{abstract}
RE S U M 0
O desmatamento na Amazônia vem alcançando números alarmantes nas últimas décadas, sendo os principais responsáveis por essas ações não apenas os grandes e médios fazendeiros, a grilagem de terra e o garimpo ilegal, como também os assentamentos de reforma agrária podem estar contribuindo com o aumento nas taxas de desmatamento. Diante desse contexto, este trabalho visa avaliar a dinâmica do uso da terra no assentamento rural Santo Antônio do Matupi, localizado no sul do estado do Amazonas. Foi realizado um estudo temporal sobre a mudança no uso e cobertura da terra de 1992 a 2018, com uso de técnica de classificação supervisionada e, a partir desse cenário, foram realizadas simulações na dinâmica do uso da terra para o período de 2028 a 2038 utilizando o método autômatos celulares de Markov (CA-MARKOV). Os resultados mostraram que no período estudado as maiores perdas foram nas florestas primárias, sendo o período mais crítico nas taxas de desmatamento registrado de 2004 a 2018, quando 63,28\% da área foi convertida para a implementação de pastagens. Os cenários futuros, com base no período estudado, indicam perda de até 5,26\% de áreas ocupadas por florestas até 2028 , e mais $5,60 \%$ até 2038 , superando $80 \%$ de área total desmatada no assentamento. $O$ estudo demonstra que o atual modelo de uso e ocupação da terra praticado no assentamento é insustentável, e que os cenários futuros se mostram bastante preocupantes, o que evidencia a necessidade de implementação efetiva de programas voltados ao desenvolvimento rural sustentável no assentamento, além do monitoramento e controle do desmatamento voltado aos atuais gestores e demais setores da sociedade preocupados com a conservação e preservação das florestas.
\end{abstract}

Palavras-chave: bioma Amazônico; reforma agrária; desflorestamento; modulo CA-Markov.

\footnotetext{
${ }^{1}$ Universidade Estadual Paulista "Júlio de Mesquita Filho" - São Paulo (SP), Brazil.

Correspondence address: Miqueias Lima Duarte - Universidade Estadual Paulista “Júlio de Mesquita Filho” - Avenida Três de Março, 511 Aparecidinha - CEP: 18087-180 - Sorocaba (SP), Brazil. E-mail: miqueiaseng@hotmail.com

Conflicts of interest: the authors declare no conflicts of interest.

Funding: Coordenação de Aperfeiçoamento de Pessoal de Nível Superior, Brasil (CAPES) (Finance Code 001) and National Council for Scientific and Technological Development (CNPq).
}

Received on: 12/07/2020. Accepted on: 03/21/2021.

https://doi.org/10.5327/Z217694781005 


\section{Introduction}

The creation of the National Plan for Agrarian Reform (PNRA), under decree no. 91.766 of October 10, 1985, has driven the colonization of the Amazon region in Brazil. Its main objective is allocating 43 million hectares for the benefit of more than 1.4 million families (Brasil, 1985). Current data show that more than 87 million hectares have been demarcated in rural settlements, of which $80.23 \%$ are located inside the Legal Amazon (Brasil, 2020a).

Currently, the Amazon has been losing a large part of its native vegetation cover due to several factors, such as disordered exploitation of wood and deforestation to benefit the agricultural sector (Congilio and Moraes, 2016; Duarte et al., 2020; Rossoni and Moraes, 2020). The tendency is that the increase in deforestation continues in the coming years mainly in the region located in the "Arc of Deforestation," which comprises the western part of the State of Acre, the southern Amazon and Pará, northern Rondônia, and Mato Grosso, in addition to the area of transition from the State of Pará to Rondonia and Maranhão (Carvalho and Domingues, 2016; Tollefson, 2018).

Studies have indicated that large and medium-sized farmers contribute the most to deforestation activities in the Amazon (Walker et al., 2013; Fearnside, 2017). However, some studies have shown that deforestation in rural settlements may be contributing significantly to deforestation in locations where settlements are concentrated (Farias et al., 2018; Duarte et al., 2020).

Although rural settlements are important means of distributing land, their implementation process, in addition to contributing to deforestation, causes a series of socioenvironmental problems, which may render sustainability unfeasible (Ávila et al., 2019). According to Moutinho et al. (2016), about $10-30 \%$ of the deforestation in the Amazon is attributed to small landholders, especially in rural settlements established by the National Institute of Colonization and Agrarian Reform (INCRA).

The increase in deforestation inside the Legal Amazon is strongly associated with the growth of cattle breeding (Walker et al., 2013). Data of the Brazilian Institute of Geography and Statistics (IBGE, 2020) point out that between 1990 and 2017, the Brazilian cattle herd increased from 147 million to 217 million animals (about 140\%) and that a large part of this increase occurs mainly in the Amazon region (264\% between 1997 and 2017). In a way, it implies the deforestation of new areas for the opening of new pastures (Mello and Artaxo, 2017; Thaler et al., 2019).

The removal of forest areas for agricultural purposes is associated with loss of water and soil quality (Fearnside, 2017), as well as changes in biological, physical, and chemical processes in natural systems (Thomaz et al., 2020). Thus, pressure on forest areas and inadequate land use are determining factors for environmental degradation, ecological imbalance, and loss of biodiversity (FAO, 2017; Thaler et al., 2019; Duarte et al., 2020).
Considering the importance of maintaining natural vegetation to ensure the stability of the environment and the effects of rural settlements on deforestation in the Amazon, it is relevant to assess the current conditions of the dynamics of land occupation in view of such dynamics of suppression of the forest and, consequently, verify the future impacts on the forest. Geographic information systems (GIS) and remote sensing are powerful and low-cost tools to investigate these processes since they allow the evaluation of historical changes using multitemporal data, in addition to building future scenarios that can be used for monitoring and planning purposes (Olmedo et al., 2015; Firozjaei et al., 2019).

Thus, this work presents the results of a case study on the time dynamics of land use and land cover changes between 1992 and 2018 in a rural settlement inside the Brazilian Amazon. Based on this dynamic, this study projects the consequences for future scenarios in 2028 and 2038. The research sought to predict the likely future conservation status of forests in view of the current soil management and use, as well as to demonstrate the feasibility of applying remote sensing and geoprocessing techniques in diagnoses and prognoses of land use and occupation in rural settlements in forest areas of the Amazon Biome.

\section{Characterization of the study area}

The study area corresponds to the Santo Antônio do Matupi Rural Settlement Project (RS Matupi), located in the municipality of Manicoré, in the southern region of the State of Amazonas, inside the Legal Amazon (Figure 1). The settlement was created through the resolution no. 148 of June 20, 1992, by the National Institute of Colonization and Agrarian Reform (INCRA) (Brasil, 2020a) and covers an area of $34,889.77$ hectares divided into 538 lots with an extension of 60 to 80 hectares.

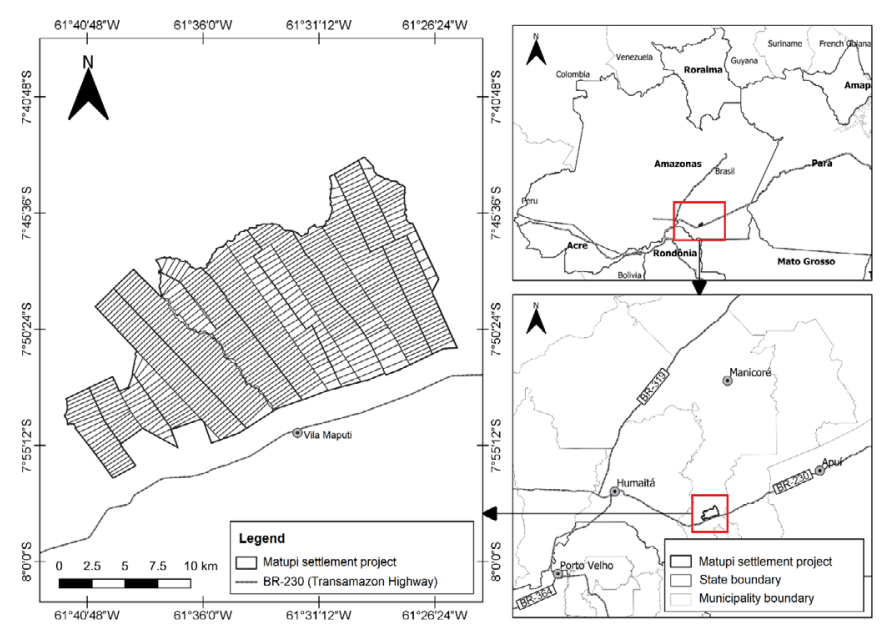

Figure 1 - Location of the Santo Antônio do Matupi rural settlement. 
The RS Matupi aimed to incorporate new areas into the regional productive process and order occupations through an implanted infrastructure, thus avoiding invasions in and speculation on land ownership and use, in addition to providing better living conditions for farmers in the region (Leal et al., 2017). As it is a conventional settlement, the RS Matupi followed the occupation and production model of the nearby states (Mato Grosso and Rondônia), which have extensive areas of forested land destined to the possibility of timber extraction and agricultural production (IDESAM, 2016).

Currently, the Technical, Social and Environmental Agrarian Reform Advisory Program (ATES) of the INCRA Regional Superintendence monitors the settlement with support from the Amazonas Sustainable Development Institute (Brasil, 2020a). It is also a part of the Green Settlement Program, which comprises a set of actions aiming to facilitate rural credit, training, and rural organization and assist in the production, sales and marketing system, technical assistance, and environmental conservation aiming a sustainable development of settlements (Brasil, 2020a).

\section{Materials and Methods}

\section{Plotting of the map of land use and land cover}

The land use and land cover maps for the period between 1992 and 2018 were prepared based on the classification of satellite images obtained by the Thematic Mapper (TM), Landsat 5, Enhanced Thematic Mapper Plus (ETM +) Landsat 7 sensors, and the Operational Land Imager (OLI) Landsat 8, both with a spatial resolution of $30 \mathrm{~m}$, obtained on the Earth Explorer website of the United States Geological Survey (USGS, 2019), at orbit/point 231/65.

The images on different dates were redesigned for the Universal Transverse Mercator coordinate system, Datum SIRGAS 2000, Zone 20 South. Then, the atmospheric correction was performed using the Dark Object Subtraction 1 (DOS1) method, as described by Leroux et al. (2018), and its color composition was made using bands 5, 4, and 3 of Landsat 5 and 7, and bands 6, 5, and 4 of Landsat 8 .

Next, supervised classification of images was performed using the software QGIS 3.2.1 (OSGEO, 2019) and the function Semi-Automatic Classification Plugin v. 6.2.2 (Congedo, 2018), as described by Duarte and Silva (2019).

The supervised classification uses the maximum likelihood method, which calculates the probability that a pixel belongs to a land cover class based on the comparison of spectral signatures obtained from samples of calibration areas referring to the land surface category. In this method, calibration areas were selected to extract the signatures of the different covers of the Earth's surface in the form of polygons on a composition of the Landsat 5, 7, and 8 images. On average, 20 samples were determined for each cover category. The dimensions of the polygons were between 10 and 20 pixels.

\section{Verifying mapping accuracy}

To verify the precision and accuracy of the mapping of land use and land cover, fieldwork was carried out between September 17 and 21, 2018, for photographic records and georeferencing of 50 samples obtained randomly, as described by Duarte and Silva (2019). This activity was performed using a Garmin 64 s global positioning system (GPS). The land use classes identified were as follows: native forest vegetation - area occupied by dense ombrophylous forest; secondary vegetation-area previously deforested in a natural regeneration process; pasture A-area occupied by pasture in good cultivation conditions; pasture $\mathrm{B}$-areas with abandoned or underused grass, showing signs of erosion and low productivity; and exposed soil-mechanized areas with no vegetation.

The analysis of classification accuracy for the other years (e.g., 1992, 1994, 1996, 1998, 2000, 2002, 2004, 2006, 2008, 2010, 2012, 2014, and 2016) was carried out by obtaining 50 samples randomly distributed on the identified areas with similar characteristics (e.g., tonality, texture, and structure) as those observed in the field for 2018. Figure 2 shows examples of points verified in the field used to validate land use classes.

From the samples obtained in the field, an analysis of classification accuracy was performed based on the construction of a confusion matrix (Fiumi et al., 2014). Then, the kappa coefficient was evaluated. This coefficient is a measure of agreement that provides an idea of the extent by which the observations depart from those expected (Landis and Koch, 1977), thus indicating the level of precision expected in interpretations. The tau agreement coefficient was also calculated, which is based on an a priori probability, which allows obtaining the expected agreement value even before verifying the mapping simulation results (Ma and Redmond, 1995).

As defined by Landis and Koch (1977), the kappa index can be classified into six classes considering the relative strength of agreement (Table 1). For the tau index, the same categories as the kappa index were considered since they are interpreted in the same way.

\section{Study of the current and future dynamics of land use}

The study of the current dynamics and changes between the years studied serves as a basis for predicting future scenarios in terms of land surface cover that may play an important role in the formulation of public policies aiming the planning and drafting of policy goals of environmental protection and conservation (Hasan et al., 2020).

To study possible changes in land use and land cover, a land change modeler (LCM) was used. The LCM considered a transition matrix based on land use change and land cover maps for the years 1998 to 2018 to identify changes in surface coverage during the analyzed period.

The cellular automaton model (CA-MARKOV) was used to study the possible future scenarios. The CA-MARKOV is a stochastic model 


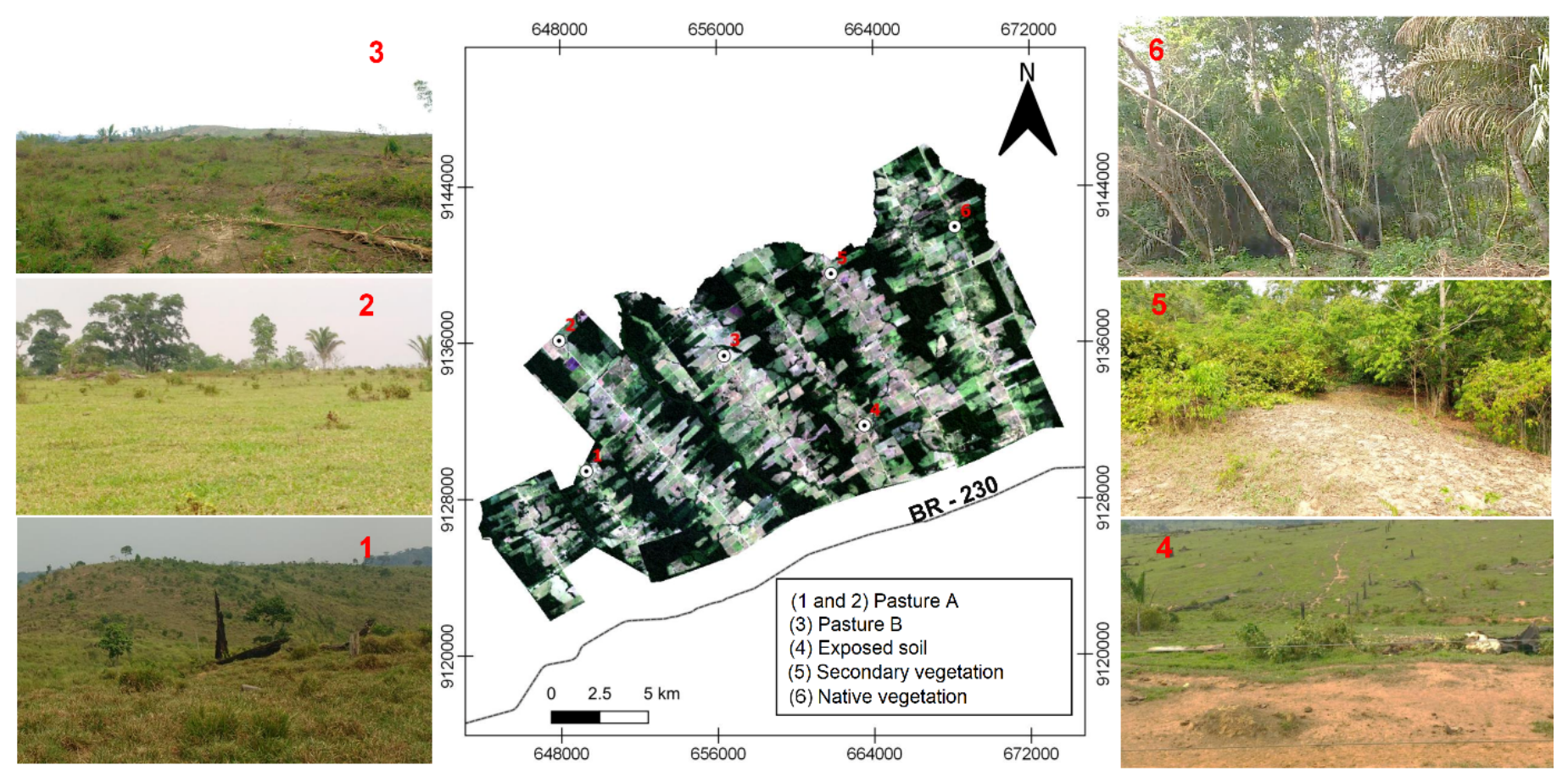

Figure 2 - Example of field verification points for validating land use classification.

Table 1 - Quality of the classification associated with kappa index values.

\begin{tabular}{|c|c|}
\hline Kappa value & Level of agreement \\
\hline$<0.00$ & None \\
\hline $0.00-0.20$ & Minimum \\
\hline $0.21-0.40$ & Weak \\
\hline $0.41-0.60$ & Moderate \\
\hline $0.61-0.80$ & Strong \\
\hline $0.81-1.00$ & Almost perfect \\
\hline
\end{tabular}

Source: Landis and Koch (1977).

that combines different variations in land use and land cover changes during a studied period (Olmedo et al., 2015; Firozjaei et al., 2019; Hasan et al., 2020). In this case, the time series was the past 20 years (1998 to 2018). This research adds to the system an element of spatial contiguity based on the probable distribution of transitions using the known period to predict future scenarios, in this case the next 20 years (2018 to 2038).

In order to test the suitability of the prediction model for future scenarios, a use forecast was generated for 2018 based on the time series from 1998 to 2008 . Its result was evaluated using the kappa coefficient between the real map and the predicted map.

\section{Results and Discussion}

\section{Land use and land cover maps}

Figure 3 shows the land use and land cover maps of the study area from 1992 to 2018.

As the cartographic series show (Figure 3), there was a significant increase in pasture classes over the forest areas, which shows the impacts of the settlement on forested areas. Table 2 shows the values related to land use and land cover in the studied area and the indicators of accuracy of the performed mapping.

Figure $4 \mathrm{~A}$ shows the values, in accumulated percentages, of changes in land use and land cover, and Figure 4B shows the deforestation rate in the studied period.

Figure 4A shows that forest losses in 1992 were less than $1 \%$ of the total settlement area and that the percentage represented by primary forest was less than $30 \%$ in 2018 . In addition, deforestation rates (Figure $4 \mathrm{~B}$ ) did not follow the same trends observed for other regions of the Amazon. This statement is based on data from the real-time deforestation detection system (DETER), which indicates a $72 \%$ decrease in global deforestation rates between 2004 and 2018 (Brasil, 2018). However, in the studied area, in the same period, there was an increase of $63.28 \%$ in deforestation, indicating that efforts to 


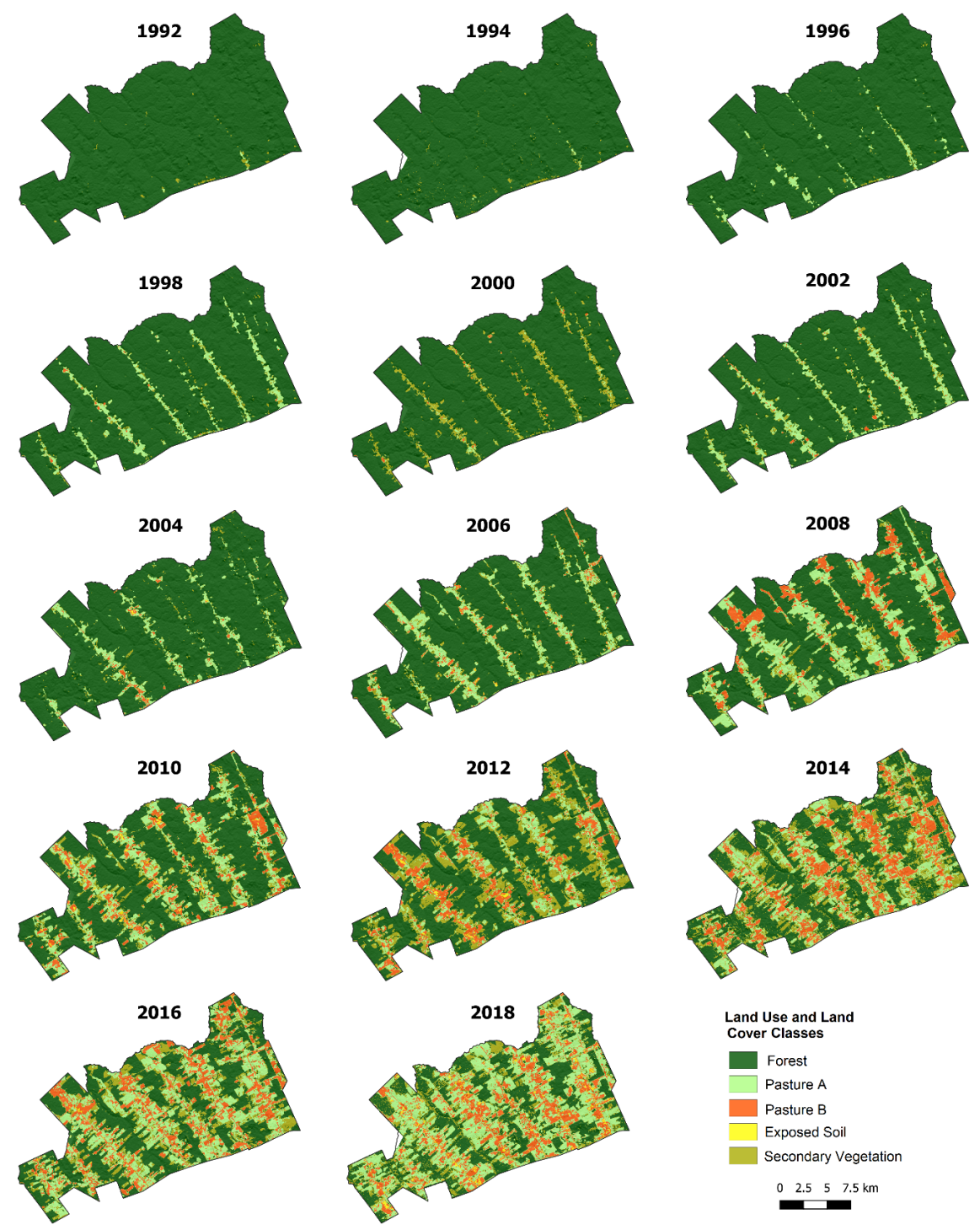

Figure 3 - Land use and land cover maps from 1992 to 2018.

contain deforestation have not yet been effective in the settlement under study.

Between 2006 and 2018, about 1,300 hectares per year of forest were deforested, totaling 16,952 hectares, which is equivalent to $73.26 \%$ of the deforestation in the settlement. The period with the greatest loss was between 2006 and 2008 (25.03\%), followed by 2012 to 2014 (17.93\%), 2010 to 2012 (15.31\%), and 2016 to 2018 (12.06\%) (except between 2008 to 2010, which presented the lowest deforestation rate in the historical series, representing about $0.56 \%$ of the total deforestation in the settlement). Between 1992 and 2004, about 320 hectares were deforested per year. The highest rates occurred from 1996 to 1998 (8.19\%), and the lowest rates were between 1992 and $1994(0.82 \%)$.

The lowest rates of deforestation observed between 1992 and 2004 in the studied area are related to the beginning of the settlement due to the lack of infrastructure and accessibility to properties, as well as high rates of tropical diseases, resulting in a lower level of anthropic activity in the settlement (Souza et al., 2018; Souza et al., 2019).

On the contrary, the highest deforestation rates between 2004 and 2018 may have been caused by the effective occupation of property owners, associated with the inefficiency of the "Command and Control" system in detecting deforestation in small areas. In addition, the 
Table 2 - Values obtained by classified images of the study area from 1992 to 2018.

\begin{tabular}{|c|c|c|c|c|c|}
\hline Class & Forest (ha) & Secondary vegetation (ha) & Pasture A (ha) & Pasture B (ha) & Exposed soil (ha) \\
\hline $1992^{*}$ & $34,361.49$ & 201.34 & 41.43 & 1.70 & 0.17 \\
\hline $1994^{* \prime}$ & $34,171.36$ & 377.84 & 56.77 & 0.45 & 0.72 \\
\hline $1998^{\star \prime}$ & $31,690.44$ & 577.30 & $2,204.79$ & 134.62 & 0.72 \\
\hline $2000^{* * ”}$ & $31,506.94$ & $2,391.96$ & 496.94 & 203.04 & 3.50 \\
\hline $2002^{*}$ & $31,033.23$ & 616.13 & 2733.6 & 220.86 & 4.57 \\
\hline $2006^{\star * ”}$ & $28,172.67$ & 858.90 & $4,720.06$ & 632.63 & 225.11 \\
\hline $2008^{* * ”}$ & $22,380.36$ & $1,553.77$ & $7,612.11$ & $2,949.56$ & 112.28 \\
\hline $2010^{* * ”}$ & $22,251.65$ & $2,310.65$ & $6,146.20$ & $3,602.79$ & 298.38 \\
\hline $2012^{\star * *}$ & $18,709.14$ & $7,813.53$ & $4,073.35$ & $3,766.01$ & 247.35 \\
\hline $2014^{\star \star »}$ & $14,559.76$ & $6,163.25$ & $7,761.33$ & $6,005.62$ & 116.41 \\
\hline
\end{tabular}

${ }^{\star}$ Kappa coefficient intervals between 0.81 and 1.00 (almost perfect); ${ }^{* *}$ kappa coefficient intervals between 0.61 and 0.80 (strong); 'tau coefficient intervals between 0.81 and 1.00 (almost perfect); "tau coefficient intervals between 0.61 and 0.80 (strong).

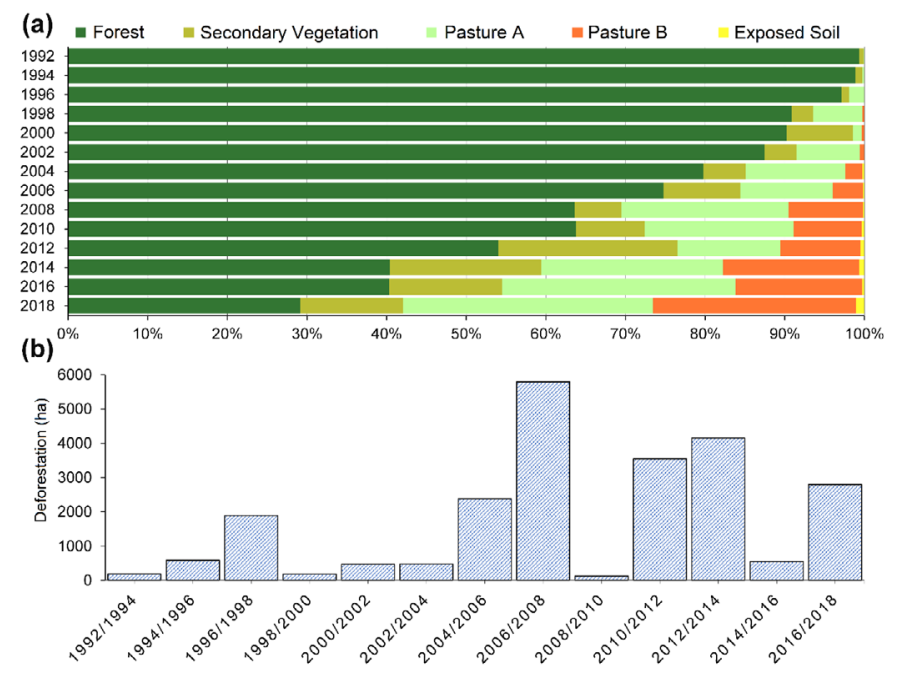

Figure 4 - (A) Accumulated percentage distribution of change in land use and land cover and (B) deforestation rate in the Santo Antônio do Matupi rural settlement between 1992 and 2018.

period of greatest forest loss coincided with an exponential increase in the cattle herd in the region, as IBGE data show (2020), which consequently led to the opening of new areas for pastures. Silva et al. (2011) described the replacement of agricultural areas for pastures in the settlement. According to the authors, this phenomenon began after 2000 and became the main economic activity of the settlement. Souza et al. (2019) described that livestock currently represents about $85.8 \%$ of the local economy (55.1\% of dairy cattle and $29.7 \%$ of beef cattle).
The implementation of the Action Plan for the Prevention and Control of Deforestation in the Legal Amazon (PPCDAm) in 2004 proved to be very efficient in controlling deforestation in large areas, that is, areas over 25 hectares (Brasil, 2020b). In smaller areas, however, as observed in this study (smaller than 10 hectares), this system proves inefficient in fulfilling its main objective, that is, to contain deforestation.

Also, the behavior of the time series up to 2000 shows that the areas occupied by secondary vegetation were larger than the other cover categories (about $6.91 \%$ of the total) compared with $2.03 \%$ of the others. As of that year, the areas occupied by pasture became predominant, indicating the dominance of livestock activity in the settlement.

In the same way, there are significant percentages (greater than $0.01 \%$ ) of areas occupied by exposed soil from 2004 onwards, a period during which the greatest losses of the forest began in the settlement and the PPCDAm was implemented. These areas occupied $<1 \%$ of the total anthropized areas, except for the period from 2002 to 2004 , during which this percentage more than doubled concerning previous years.

Currently, deforested areas are predominantly occupied by pasture in good cultivation conditions $(38.42 \%)$, followed by degraded pastures (15.75\%), vegetation in stages of regeneration $(8.75 \%)$, and exposed soil (3.95\%). These percentages total $66.87 \%$ of the settlement area.

Farias et al. (2018) related this increase in deforestation in the Amazon to the increase in the prices of commodities such as meat and soy. Indeed, the data of the IBGE (2020) on the cattle herd in the munici- 
pality point to an increase of $200 \%$ in the number of animals between 2004 and 2018. Despite being local, these data reflect the increase in the size of the cattle herd in the settlement since it is the main area with anthropic occupation in the municipality, thus justifying the dominance of the agricultural activity, which occupied about $54.29 \%$ of the area in 2018. Also, the fact that this type of activity has a low cost and is easy to implement may help to justify its greater occurrence in the settlements (Ávila et al., 2019).

The areas occupied by degraded pasture had significant percentages (> 0.01\%) from 1998 onwards. Since then, these areas increased proportionally to the areas occupied by pastures in good conditions, and in 2018 , they represented about $15.75 \%$ of the total area in the settlement. On the contrary, the presence of areas occupied by secondary vegetation (regenerating vegetation) in large percentages can be associated with low productive pastures and fallow and traditional itinerant agriculture. With the subsequent abandonment of these areas, "capoeiras" (brushwood areas) appear as an initial natural regeneration process (Dick and Schumacher, 2015).

\section{Forecasting future scenarios}

The construction of scenarios for 2028 and 2038 based on the historical series from 1998 to 2018, considering the real map forecast for 2018, showed a kappa coefficient of 0.80 , indicating a high consistency (Landis and Koch, 1977). Thus, the transition matrix considering the historical series, at least theoretically, can be a good predictor to explain possible changes in future years (Munthali et al., 2020).

Table 3 shows the estimated transition rates from 1992 to 2018 and the probable transition rates from 2018 to 2028 and from 2028 to 2038. Negative values mean losses and positive values mean gains.

From 1992 to 2018, forest losses were $66.87 \%$, while the forecast for losses from 2018 to 2028 is $7.53 \%$ of deforested areas. For the period 2028 to 2038 , the scenario indicates a $5.60 \%$ loss, that is, a forecast of replacement of forest in $80 \%$ of the area at the end of the period. This high final percentage is in disagreement with the Law no. 12.651 (Brasil, 2012). For rural properties, including settlements, $80 \%$ of native vegetation must be preserved in legal reserves (LR). No matter whether deforestation occurs, it should not compromise the per- manent preservation area (PPA); otherwise, the owner of the area is obliged to recompose the vegetation.

The deforestation carried out before 2008 would eventually not be the object of an ecological restoration, considering that the offender would not be fined, for example, for irregularly deforesting the LR vegetation before July 22, 2008. Therefore, the offender would not be obliged to recompose the forest (Brasil, 2012).

In the 1992 and 2018 time series, deforested areas were converted predominantly into pastures in good condition, degraded pastures and areas of secondary vegetation, and small percentages of exposed soil. In the scenario forecast for 2028, the deforested areas follow the same trend, with emphasis on an increase of $5.26 \%$ in areas occupied by pastures in good conditions (from 13,341.20 ha in 2018 to $15,508.41$ ha in 2028), followed by an increase of $2.72 \%$ in pastures in degraded conditions (from 5,451.70 ha in 2018 to 6,529.71 ha in 2028 ), and an increase of $0.91 \%$ in areas in natural regeneration (from $3,226.92$ ha in 2018 to $3,544.22$ ha in 2028). The exception is a decrease of $1.36 \%$ in areas occupied by exposed soil (from 769.56 ha in 2018 to 413.17 ha in 2028).

If no protective measures are taken, in the 2038 scenario, following the same trend as in the previous period, the areas occupied by pasture in good cultivation conditions will increase by $4.52 \%$ (from $15,508.41$ ha in 2028 to $17,074.02$ ha in 2038), and the areas occupied by degraded pasture will increase by $2.02 \%$ (from 6,529.71 ha in 2028 to $7,227.71$ ha in 2038). The exception is for areas in stages of natural regeneration and exposed soils, which will decrease by $0.77 \%$ (from $3,544.22$ ha in 2028 to $3,277.14$ ha in 2038) and $0.18 \%$ (from 413.17 ha in 2028 to 351.47 ha to 2038 ), respectively.

The prediction of decreases in the natural regeneration area in 2018-2038 is probably due to the fact that this vegetation has reached a dimension that allows its use, culminating in its suppression, or even because the occupied area will be destined to crops or to expanding pastures. Figure 5 shows the predicted maps of land use/land cover change for 2028 and 2038.

The maps of 2028 and 2038 (Figure 5) serve as a basis for the formulation of public policies aiming at the protection and management of land use and land cover in general since they can not only provide scenarios of changes that may occur but also make it possible to predict

Table 3 - Rates of change in land use/land cover for 2028 and 2038.

\begin{tabular}{|c|c|c|c|c|c|c|c|}
\hline \multirow[b]{2}{*}{ Land use class } & \multicolumn{4}{|c|}{ Area (\%) } & \multicolumn{3}{|c|}{ Change of use (\%) } \\
\hline & 1992 & 2018 & 2028 & 2038 & $1992-2018$ & $2018-2028$ & $2028-2038$ \\
\hline Forest & 99.29 & 32.41 & 24.88 & 19.29 & -66.87 & -7.53 & -5.60 \\
\hline Secondary vegetation & 0.58 & 9.32 & 10.24 & 9.46 & 8.75 & 0.91 & -0.77 \\
\hline Pasture A & 0.12 & 38.54 & 44.80 & 49.33 & 38.42 & 5.26 & 4.52 \\
\hline Pasture B & 0.00 & 15.75 & 18.86 & 20.88 & 15.75 & 2.72 & 2.02 \\
\hline Exposed soil & 0.00 & 3.95 & 1.19 & 1.01 & 3.95 & -1.36 & -0.18 \\
\hline
\end{tabular}


future impacts. Therefore, this type of mapping is an important tool for the analysis of environmental degradation resulting mainly from the loss of forests since, with the removal of natural vegetation, there is a compromise of several ecosystem services considered essential for the quality of life of the population.

The results of this study also make it possible to state that the combination of GIS tools and remote sensing techniques is efficient for mapping changes in land use and land cover on a small scale, as they provide essential information about the spatial and temporal dynamics in the settlement and allow predicting possible changes in these patterns.

Regarding the implementation process, there is a close relationship with the increase in deforestation in the settlement, where there is no minimum infrastructure. Even the way by which incentive practices aim to carry out activities that do not contribute to environmental sustainability causes a social distortion of the real beneficiaries of agrarian reforms. Thus, it is of paramount importance to effectively implement programs aiming a sustainable rural development in the settlement, such as the provision of technical assistance to improve agricultural productivity in already deforested areas and the expansion of agricultural credit for environmentally friendly producers, in addition to compensating settlers for the environmental services they provide (Moutinho et al., 2016).

\section{Conclusions}

The mapping of land use and land cover between 1992 and 2018 in the settlement made it possible to verify that the period with the high- est deforestation rates was between 2008 and 2018, which represents about $73.26 \%$ of the accumulated deforestation. In 2018, only about $30 \%$ of the primary forest remains in the settlement. The predominant class of land use and land cover is pasture. Livestock is the predominant economic activity in the settlement.

If measures are not taken, the scenarios for 2028 and 2038 indicate the same trend of land use and coverage as of until 2018, which is marked by a landscape formed predominantly by pastures since the current occupation model in the settlement is represented by this category of land use, thereby exerting pressure on native forests.

In view of the predictions, urgent measures are needed not only to provide the minimum infrastructure conditions for settlers to survive but also to directly relate this settlement policy to the maintenance of legal reserves and the protection of permanent preservation areas. In addition, the adoption of stricter control policies and mandatory registration of properties in the CAR are important to prevent any further situations that might result in deforestation.

Finally, this study shows the urgency of implementing more effective measures aiming to monitor settlements and maintain the settled families, especially actions that ensure environmental sustainability focused on reducing the suppression of forests, so that settlements change landscapes in a positive way.

\section{Acknowledgments}

The authors would like to thank the United States Geological Survey (USGS) for the availability of data.
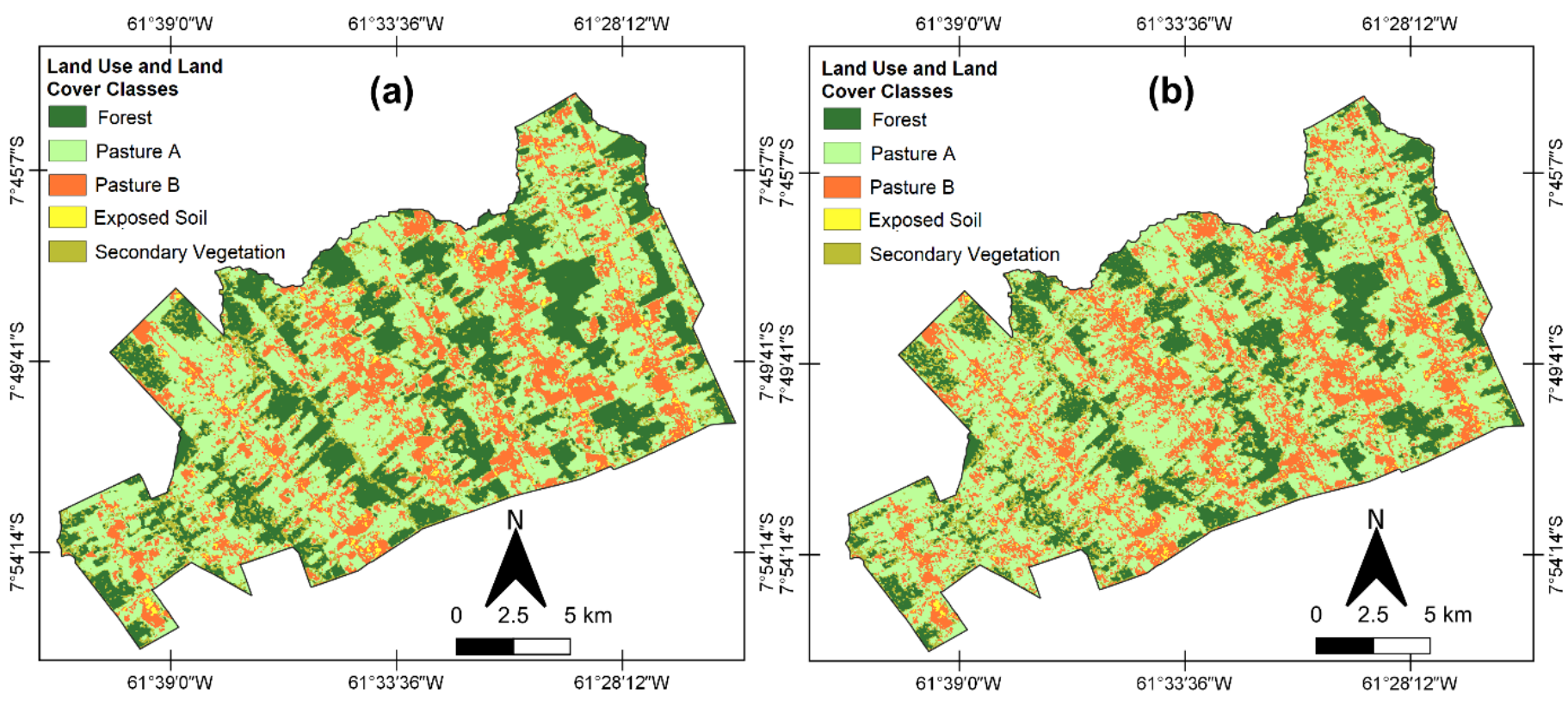

Figure 5 - Future scenarios of change in land use/land cover in the Santo Antônio do Matupi rural settlement: (A) 2028 and (B) 2038. 


\section{Contribution of authors:}

Duarte, M.L.: Investigation, Methodology, Formal analysis, Writing — original draft; Souza, J.A.P.: Investigation, Methodology, Writing — review and editing; Castro, A.L.: Investigation, Methodology, Writing — review and editing; Lourenço, R.W.: Conceptualization, Supervision, Project administration, Writing — review and editing.

\section{References}

Ávila, S.R.S.A.; Ávila, M.; Bernardi, J.V.E.; Couto Júnior, A.F., 2019. Estudo exploratório sobre dinâmica do desmatamento em assentamentos localizados no território portal da Amazônia. Retratos de Assentamentos, v. 22, (1), 139152. http://dx.doi.org/10.25059/2527-2594/retratosdeassentamentos/2019. v22i1.330.

Brasil. 1985. Presidência da República. Decreto n 91.766, de 10 de outubro de 1985. Aprova o Plano Nacional de Reforma Agrária, e dá outras providências (Accessed January 2, 2019) at: http://www.planalto.gov.br/ccivil_03/Atos/ decretos/1985/D91766.html.

Brasil. 2012. Lei 12.651 de 25 de maio de 2012. Dispõe sobre a proteção da vegetação nativa. Congresso Nacional (Accessed February 18, 2021) at: http:// www.jusbrasil.com.br/legislacao/1032082/lei-12651-12.

Brasil. 2018. Instituto Nacional de Pesquisas Espaciais. Monitoramento do Desmatamento da Floresta Amazônica Brasileira por Satélite (Accessed November 5, 2020) at: http://www.obt.inpe.br/OBT/assuntos/programas/ amazonia/prodes.

Brasil. 2020a. Instituto Nacional de Colonização e Reforma Agrária. Incra nos Estados - Informações gerais sobre os assentamentos da Reforma Agrária (Accessed November 12, 2020) at: https://painel.incra.gov.br/ sistemas/index.php.

Brasil. 2020b. Ministério do Meio Ambiente. Plano de ação para a prevenção e controle do desmatamento na Amazônia Legal (Accessed November 8, 2020) at: http://www.mma.gov.br.

Carvalho, T.S.; Domingues, E.P., 2016. Projeção de um cenário econômico e de desmatamento para a Amazônia Legal brasileira entre 2006 e 2030. Nova Economia, v. 26, (2), 585-621. http://dx.doi.org/10.1590/0103-6351/2665.

Congedo, L., 2018. Semi-Automatic Classification Plugin Documentation (Accessed December 12, 2019) at: https://fromgistors.blogspot.com/p/semiautomatic-classification-plugin.html.

Congilio, C.R.; Moraes, C.S., 2016. Violência agrária e desmatamento: corolários das políticas de Estado e das lutas sociais no sudeste paraense. Lutas Sociais, v. 20, (37), 155-167. 2016.

Dick, G.; Schumacher, M.V., 2015. Relações entre solo e fitofisionomias em florestas naturais. Ecologia e Nutrição Florestal, v. 3, (2), 31-39. http://dx.doi. org/10.5902/2316980X16741.

Duarte, M.L.; Brito, W.B.M.; Silva, T.A.; Casto, A.L., 2020. Padrões e causas do desmatamento no Baixo Acre, região oeste da Amazônia brasileira. Journal of Environmental Analysis and Progress, v. 5, (1), 117-127. https://doi. org/10.24221/jeap.5.1.2020.2790.117-127.

Duarte, M.L.; Silva, T.A., 2019. Avaliação do desempenho de três algoritmos na classificação de uso do solo a partir de geotecnologias gratuitas. Revista de Estudos Ambientais, v. 21, (1), 6-16. http://dx.doi.org/10.7867/19831501.2019v21n1p6-16.
Farias, M.H.C.S.; Beltrão, N.E.S.; Cordeiro, Y.E.M.; Santos, C.A., 2018. Impactos dos assentamentos rurais no desmatamento da Amazônia. Mercator, v. 17, 1-20. http://dx.doi.org/10.4215/rm2018.e17009.

Fearnside, P.M., 2017. Deforestation of the Brazilian Amazon. Environmental Science. https://doi.org/10.1093/acrefore/9780199389414.013.102.

Firozjaei, M.K.; Sedighi, A.; Argany, M.; Jelokhani-Niaraki, Arsanjani, J.J., 2019. A geographical direction-based approach for capturing the local variation of urban expansion in the application of CA-Markov model. Cities, v. 93, 120-135. https://doi.org/10.1016/j.cities.2019.05.001.

Fiumi, L.; Congedo, L.; Meoni, C., 2014. Developing expeditious methodology for mapping asbestos-cement roof coverings over the territory of Lazio Region. Applied Geomatics, v. 6, (1), 37-48. https://doi.org/10.1007/s12518-014-0124-1.

Food and Agriculture Organization - FAO. 2017. FAOSTAT Statistical database (Accessed November 1, 2019) at: http://www.fao.org/faostat/en/\#data.

Hasan, S.; Shi, W.; Zhu, X.; Abbas, S.; Khan, H.U.A., 2020. Future simulation of land use changes in rapidly urbanizing south China based on land change modeler and remote sensing data. Sustainability, v. 12, (11), 4350. https://doi. org/10.3390/su12114350.

Instituto Brasileiro de Geografia e Estatística - IBGE. 2020. Dados por cidade (Accessed August 12, 2020) at: https://cidades.ibge.gov.br/brasil/am/manicore/ panorama.

Instituto de Conservação e Desenvolvimento Sustentável da Amazônia IDESAM. 2016. Matupi ganha primeira área de pecuária sustentável. IDESAM, Manaus (Accessed February 22, 2021) at: https://idesam.org/conteudo/emcampo/matupi-ganha-primeira-area-de-pecuaria-sustentavel/.

Landis, J.; Koch, G.G., 1977. The measurements of agreement for categorical data. Biometrics, v. 33, (1), 159-179.

Leal, M.L.M.; Silva, V.V.; Furlan, J.Â.; Souza, A.L., 2017. Uso da terra e a legislação florestal no projeto de assentamento Matupi, AM. Boletim de Geografia, v. 35, (1), 122-133. http://dx.doi.org/10.4025/bolgeogr.v35i1.31897.

Leroux, L.; Congedo, L.; Bellón, B.; Gaetano, R.; Bégué, A., 2018. Land Cover Mapping Using Sentinel-2 Images and the Semi-Automatic Classification Plugin: A Northern Burkina Faso Case Study. In: BAGHDADI et al. QGIS and Applications in Agriculture and Forest, v. 2, 119-151. https://doi. org/10.1002/9781119457107.ch4.

Ma, Z.; Redmond, R.L., 1995. Tau coefficients for accuracy assessment of classification of remote sensing data. Photogrammetric Engineering and Remote Sensing, v. 61, (4), 435-439.

Mello, N.G.R.; Artaxo, P., 2017. Evolução do Plano de Ação para Prevenção e Controle do Desmatamento na Amazônia Legal. Revista do Instituto de Estudo Brasileiros, (66), 108-126. http://dx.doi.org/10.11606/issn.2316-901x. v0i66p108-129.

Moutinho, P.; Guerra, R.; Azevedo-Ramos, C. 2016. Achieving zero deforestation in the Brazilian Amazon: What is missing? Elementa: Science 
of the Anthropocene, v. 4, 000125. https://doi.org/10.12952/journal. elementa.000125.

Munthali, M.G.; Mustak, S.; Adeola, A.; Botai, J.; Singh, K.; Davis, N., 2020. Modelling land use and land cover dynamics of Dedza district of Malawi using hybrid Cellular Automata and Markov model. Remote Sensing Applications: Society and Environment, v. 17, 100276. https://doi.org/10.1016/j. rsase.2019.100276.

Olmedo, M.T.C.; Pontius Jr., R.G.; Paegelow, M.; Mas, J.F., 2015. Comparison of simulation models in terms of quantity and allocation of land change. Environmental Modelling \& Software, v. 69, 214-221. https://doi.org/10.1016/j. envsoft.2015.03.003.

OSGEO - QGIS Development Team. 2019. QGIS Geographic Information System. Open Source Geospatial Foundation Project (Accessed September 8, 2019) at: http://qgis.osgeo.org.

Rossoni, R.A.; Moraes, M.L., 2020. Agropecuária e desmatamento na Amazônia Legal Brasileira: uma análise espacial entre 2007 e 2017. Geografia em Questão, v. 13, (3), 130-148. https://doi.org/10.48075/geoq.v13i3.23536

Silva, V.V.; Vettorazzi, C.A.; Padovani, C.R., 2011. Assentamento rural e a dinâmica da paisagem. In: XV Simpósio Brasileiro de Sensoriamento Remoto, Curitiba. Anais... INPE, São José dos Campos, pp. 7000-7006.

Souza, A.L.; Silva, V.V.; Schweickardt, K.H.S.; Lucas, M., 2018. Fatores socioeconômicos e ambientais do assentamento Matupi, Manicoré, Amazonas.
In: V Seminário Internacional em Ciência do Ambiente e Sustentabilidade na Amazônia. Manaus, pp. 1-11.

Souza, A.L.; Silva, V.V.; Schweickard, K.H.S.; Melo, P.R.U.; Lanua, L., 2019. Questões sociais, econômicas e ambientais em uma área de reforma agrária: projeto de assentamento Matupi. Terceira Margem Amazônia, v. 5, (13), 129143. https://doi.org/10.36882/2525-4812.2019v5i13p\%25p.

Thaler, G.M.; Viana, C.; Toni, F., 2019. From frontier governance to governance frontier: The political geography of Brazil's Amazon transition. World Development, v. 114, 59-72. https://doi.org/10.1016/j.worlddev.2018.09.022.

Thomaz, E.L.; Nunes, D.D.; Watanabe, M., 2020. Effects of tropical forest conversion on soil and aquatic systems in southwestern Brazilian Amazonia: A synthesis. Environmental Research, v. 183, 109220. https://doi.org/10.1016/j. envres.2020.109220.

Tollefson, J., 2018. Desflorestation ticks up in Brazil's savannah. Nature. http:// dx.doi.org/10.1038/d41586-018-05695-9.

United States Geological Survey - USGS. 2019 (Accessed Nomveber 2, 2019) at: https://earthexplorer.usgs.gov.

Walker, N.F.; Patel, S.A.; Kemel, A.B.K., 2013. From Amazon Pasture to the High Street: Deforestation and the Brazilian Cattle Product Supply Chain. Tropical Conservation Science, v. 6, (3), 446-467. https://doi. org/10.1177/194008291300600309. 